\title{
NATURAL AND ANTHROPOGENIC FACTORS AS TAPHONOMIC AGENTS IN THE DIFFERENTIAL PRESERVATION OF PALEONTOLOGICAL REMAINS FROM THE FOSSIL DEPOSIT “LAS LLANADAS”, CENTRAL CUBA
}

\section{Factores naturales y antropogénicos como agentes tafonómicos en la preservación diferencial de restos paleontológicos del depósito fosilífero "Las Llanadas", Cuba Central}

\author{
Joao G. Martínez-López
}

Paleontología de Vertebrados (Curador de Mamíferos Fósiles). Grupo de Paleogeografía y Paleobiología, Museo Nacional de Historia Natural de Cuba (MNHNC). Obispo No.61, Plaza de Armas, Habana Vieja, La Habana, Cuba.jogamalo76@gmail.com; cubansloth@gmail.com.

\section{ABSTRACT}

The results of a taphonomic analysis carried out on the vertebrate fossil deposit "Las Llanadas", Sancti Spíritus, Cuba, are presented. The origin of the deposit is analyzed through features of the accumulated sediments, combined with the geological structure of the study area. The type of fossiliferous deposit represented was determined according to the categorizations proposed for Cuba by several authors. Differential preservation registered, between the recent material and the fossil and subfossil material, was analyzed by considering the mechanisms of taphonomic alteration identified as direct evidence of specific biostratinomic and fossildiagenetic processes to which the extracted remains were subjected. Anthropogenic and natural factors are discussed as responsible for the current accumulation features of the deposit. The historical reconstruction of the paleontological interventions on the site, during the last century, had been an important element to understand the features of the current fossil assemblage.

Keywords: taphonomic, preservation, anthropogenic, deposits.

\section{RESUMEN}

Se presentan los resultados de un análisis tafonómico realizado en el depósito de vertebrados fósiles "Las Llanadas", Sancti Spíritus, Cuba. El origen del yacimiento se analiza a través de las características de los sedimentos acumulados, combinados con la estructura geológica del área de estudio. El tipo de depósito fosilífero fue determinado de acuerdo a las categorizaciones propuestas para Cuba por varios autores. La preservación diferencial registrada, en materiales recientes y materiales fósiles y subfósiles, fue analizada considerando los mecanismos de alteración tafonómica, identificados como la evidencia directa de procesos bioestratinómicos y fósildiagenéticos específicos, a través de los cuales se sometieron los restos extraídos. Se discuten factores antropogénicos y naturales como máximos responsables de las características de acumulación actuales en el depósito. La reconstrucción histórica de las intervenciones paleontológicas en el sitio durante el pasado siglo, ha sido un elemento importante para comprender las características de la acumulación fósil actual.

Palabras clave: tafonómico, conservación, antropogénicos, depósitos.

\section{INTRODUCTION}

A large number of significant Cuban fossil deposits have been heavily explored, primarily during the nineteenth and twentieth centuries. In most cases, Cuban and foreign professional naturalists, as well as many science enthusiasts, have extracted paleontological materials of 
great importance. Thanks to many of those explorations and extractions, the most relevant fossil species are now known to Cuban science. Unfortunately, the whereabouts many remains of great value are now no longer known, and these items can therefore no longer be subjected to analysis. These explorations and extractions, inevitably, altered the deposits, and these alterations have to be taken into consideration during any taxonomic and taphonomic study.

The fossil deposit that is object of study in the present work, known as "Las Llanadas", is no exception. It constitutes, within the historical development of Cuban paleontology, the second most important fossil deposit of vertebrates for Cuban science. The remains extracted from it are referenced in various publications (Torre, 1910; Brown, 1913; Torre and Matthew, 1915; Torre, 1917; Matthew, 1918, 1919, 1931; Matthew and Paula, 1959; Morgan et al., 1993; Arredondo, 1999; Aranda et al., 2017), allowing researchers to identify two of the three new genera of sloths (Torre and Matthew, 1915; Matthew, 1931) proposed at that time: Miocnus and Microcnus, which were subsequently systematically updated (in biological sense) as Acratocnus (Matthew and Paula, 1959) and Neocnus (White and MacPhee, 2001), respectively (see Silva et al., 2007: 12-15). This deposit was re-excavated by the Paleogeography and Paleobiology Group of the National Museum of Natural History of Cuba (MNHNC), in April 2013.

With a few exceptions (namely, Silva, 1974; Iturralde-Vinent et al., 2000; Arredondo and Villavicencio, 2004; Díaz-Franco, 2005; Jiménez et al., 2005; Condis, 2010; Rojas-Consuegra et al., 2012), taphonomic analyses in Cuba, particularly for vertebrate paleontology, are scarce. This work constitutes a step forward in the field of vertebrate taphonomy, and adds important elements to establish a coherent relationship between the taphonomic alterations identified on the paleontological remains (fossilized or not) and the possible ways in which the deposit was originated. There is not exist detailed descriptions of the paleontological materials collected during the previous century until 2013. Some comments about the preservation of the paleontological remains can be found in Matthew (1919: 166), Paula (1956: 423), Matthew and Paula (1959: 11-12), and recently, in Aranda et al. (2017: 116).

The first element to consider was the anthropic alterations that occurred in the paleontological deposit from the beginning of the 20th century until 2013. In this way, historical events related to human interventions in the deposit, with scientific purposes or not, were added to the taphonomic analysis. This allowed abetterunderstanding about the state of conservation of the remains in general and the current characteristics of the fossil accumulation studied. It is also considered important to analyze the current geographical information of the area (soil, lithology, vegetation, etc.) where the paleontological deposit is located, which represents a continuum of assimilation of multiple changes over time that reflects, in part, the geodynamics of the site It also analyzes the characteristics of the deposit, its morphology and position fundamentally, which makes it an exceptional fossil remains collector, unlike other similar structures in the same geographical area, which were also explored but without satisfactory results.

On the other hand, it is known that the taxonomic composition of the fossil deposit responds to very different past environments (Aranda et al., 2017), for this case, lacustrine type, therefore, assessing the paleogeographic evolution of the area is not a factor to dismiss. Sea level changes recorded between $140 \mathrm{kyr}$ BP and almost the last stage of the Holocene (8-4 kyr BP) can help estimate a chronological period for the origin of the deposit.

Finally, the possible types of fossil production (biogenic or tafogenic) that make up the current accumulation are analyzed. The mechanisms of taphonomic alteration that correspond to the stages biostratinomy and fosildiagenesis, responsible for the preservation of the elements or taphonomic entities (bone and tooth remains in general), are also evaluated. 


\section{OBJECTIVES}

-Determinate the mechanisms of taphonomic alteration (anthropic and natural) and the biostratinomic and fosildiagenetic factors, that contributed with the differential preservation of the paleontological remains.

-Analyze the paleogeographic characteristics of the deposit area that favored the taxonomic inventory, accumulation, and conservation of the remains found.

\section{MATERIALS AND METHODS}

Features of the Study Area. The study area is located in Yaguajay, Sancti Spíritus, Cuba (Fig. 1), at 22'12'51.999" N and 79'6'16.998' W and more than $150 \mathrm{~m}$ a. s. 1., on an elevation named Lomas de la Canoa, to the north of Jatibonico mountain. It measures approximately $10.5 \mathrm{~km}$ by $2.5 \mathrm{~km}$ and reaches a maximum height of $264 \mathrm{~m}$ a. s. 1. (Comisión Nacional de Nombres Geográficos, 2000:60). Its paleontological deposits extend over various stages of the Pleistocene-Holocene transition (Mayo, 1970; Acevedo and Arredondo, 1982; Acevedo, 1983; Iturralde-Vinent, 2003), as do most Cuban mammal deposits (Silva et al., 2007).

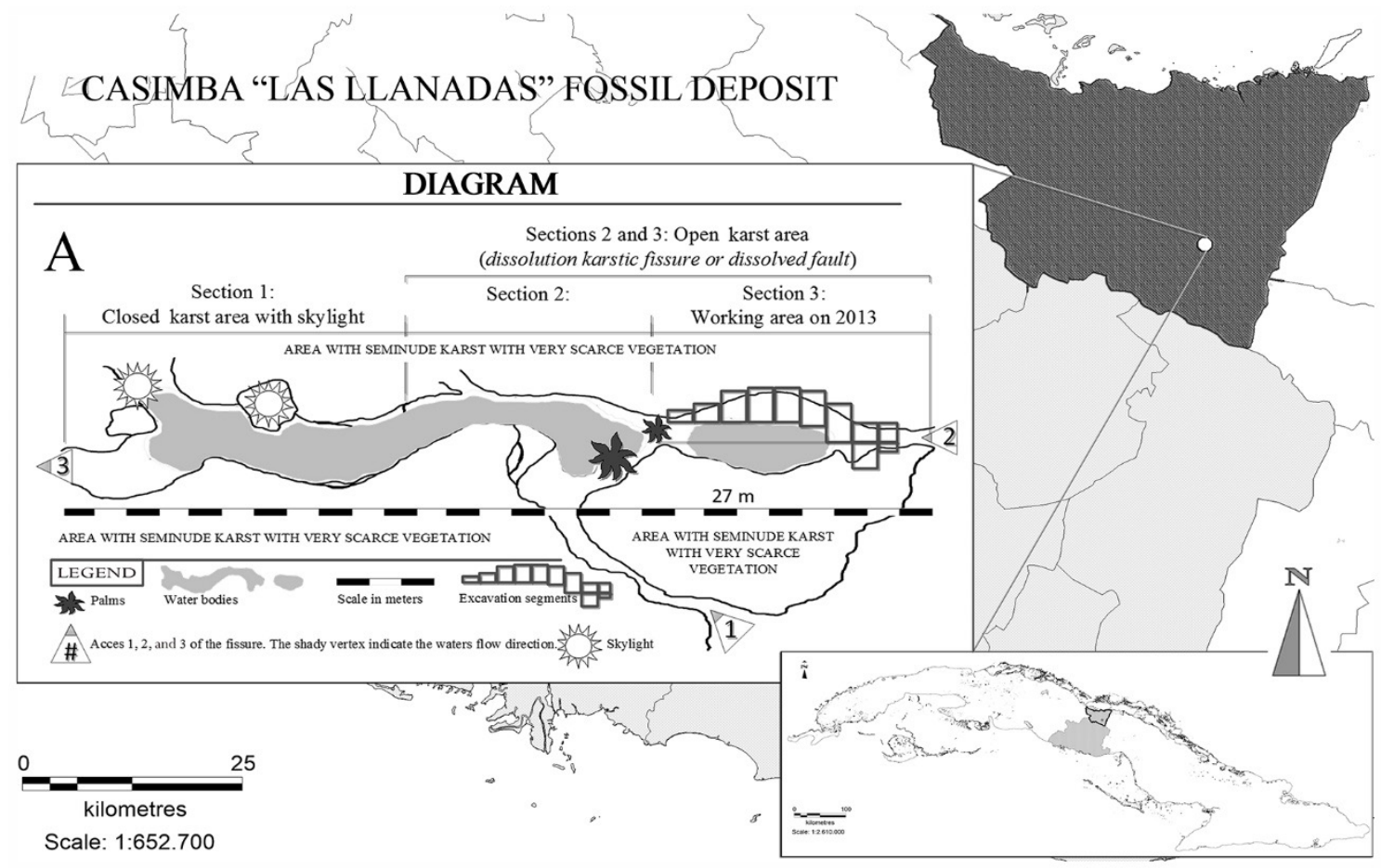

Figure 1. Fossil deposit "Las Llanadas", Sancti Spíritus, central Cuba: Geographical location and (A) general plan view, showing the excavated segments in 2013. The ends of the scale mark the longitudinal extent of the deposit.

The geographic components of the area (lithology, soil type and sediments, altimetric levels, vegetal cover, soil humidity, among others) were summarized from Skwaletski and Iturralde-Vinent (1971), Iturralde-Vinent (1972), Núñez et al. (1988), Arceo and Salinas (1994), Instituto de Suelos, MINAG, Cuba (1999), Iturralde-Vinent and MacPhee (1999), Jaimez and Gutiérrez (2010), Iturralde-Vinent and MacPhee (2004). Some criteria of sediment composition were established in consultation with Dr. Efrén Jaimez Salgado, of the Instituto de Geofísica y Astronomía (IGA), Cuba. 
According to the references cited above, it is possible to summarize the features of the study area as follows:

1. Typical mesophilic semi-deciduous forest, with elevations and depressions and with roads and transept products of human action.

2. Traces of karst erosion by infiltration, with a significant hydric paleo-regime of surface and groundwater, produced at certain stages, probably the Late Pleistocene and Holocene.

3. Sedimentary rocks mainly with a very rich fossil record because of their origin and formation due to dragging, accumulation and deposition of materials from the earth's surface (mountains, hills, and high plains); geological formations, such as Palenque, Purio, Margarita, Mata, and Vilato, corresponding to the denominated Complex I (carbonated), with almost no terrigenous material and intense cracking and fragmentation.

4. Altimetry showing seven ranges with a maximum height of $500 \mathrm{~m}$ above the sub montane of Sierra de Jatibonico, with the altimetry range for the area of the deposit classified as high altitude (200-300 $\mathrm{m}$ a. s. 1.).

5. An underground drainage pattern associated with the cracking of carbonate rocks, where faults, joints, and stratification planes are appreciated; the underground drainage follows the areas of greatest weakness and maximum gradient, with a general orientation from south to north, which can be determined by the chemical-physical nature of water associated with karst springs located in this direction.

6. Karst infiltration processes and groundwater associated with drainage that flows through cracks, leptoclases and stratification planes have played an essential role in the evolution of the karst landscape, mainly conditioned by the cracking and lithology pattern, where depressions similar to deposit "Las Llanadas" have been observed.

7. Typical soils that are brown sialitic, brown carbonated type, with an alkaline $\mathrm{pH}$, low salt, determining a relatively sparse vegetation that uses cracks in the karstic rocks to access the subsoil humidity, and the accumulation of litter for their development, with the accumulated sediment having a high humidity during most of the year, and a dark brown to black color, resembling of peat [Hemic type (D5.1)] according to the FAO (2009) classification.

Structure of the Fossil Deposit. The fossil deposit is recognized mainly in literature as a casimba (Torre, 1910; Matthew, 1918, 1919, 1931; Matthew and Paula, 1959; Silva et al., 2007) because, for most of the year, it has a superficial accumulation of water. However, Brown (1913) is the first to classify it as a crack in the limestone, or a cave-fissure, formed by the action of water. What was commonly considered in the previous works as the main entrance of the crack of the cave, is actually the water outlet, which formed a hole that morphologically corresponds to the intensity of the water flow in the past (see Fig. 5 in Torre, 1910; Brown, 1913, p. 222). According to Brown (1913), the geological and geographical criteria contributed to classify it as a karstic dissolution fissure (see Fig. 1A).

The 2013 excavation area is located at section No. 3 of the deposit (see Fig. 1A), and it was divided into nine segments, 0-1 (West) to 8-9 (East). More than 2000 pieces were extracted (Fig. 2), mainly fragmented into small pieces. The assemblage lacks phalanges, vertebrae, astragali, and calcanea; in general, it consists of bones of low taxonomic resolution and high taphonomic durability according to the criteria of Fernández-López $(2000,2005)$. 


\section{CUMMULATIVE BONE REMAINS BY SQUARE (2069) IN SECTION 3}

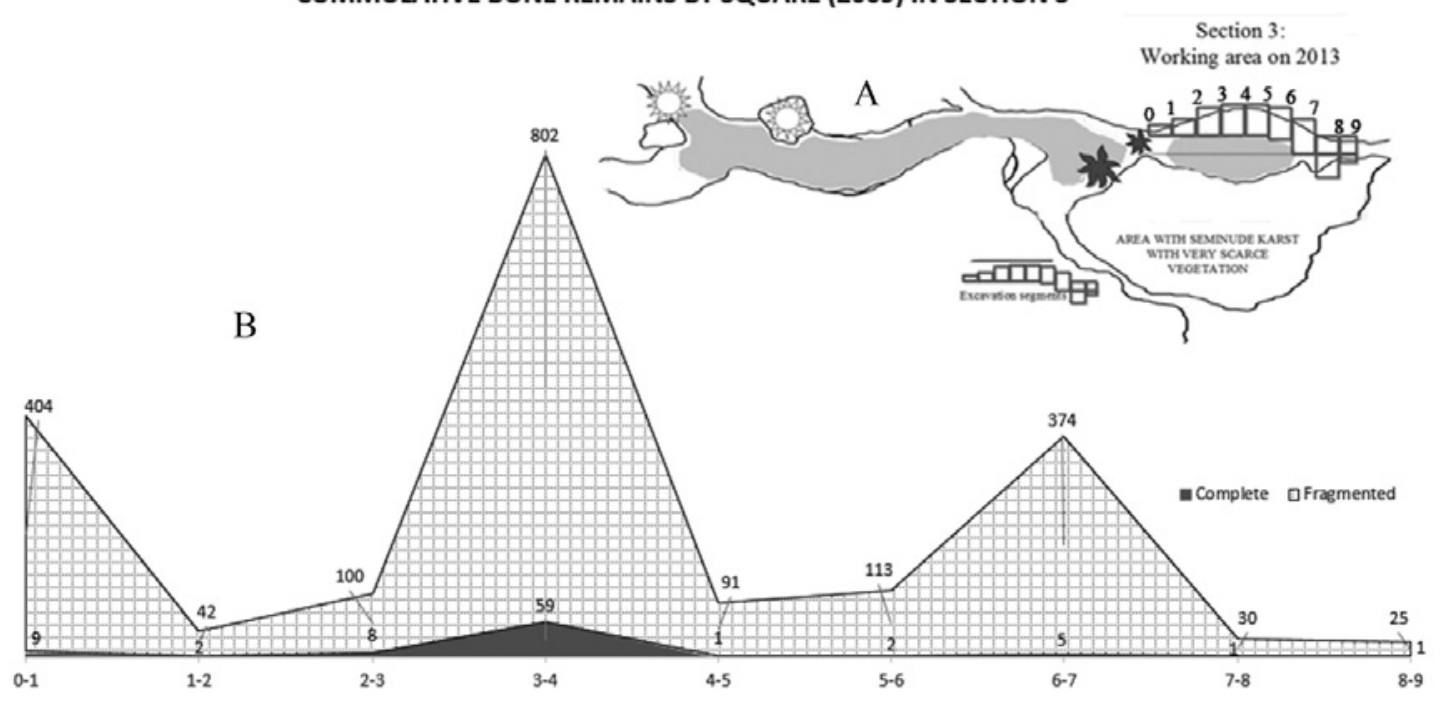

Figure 2. Fossil accumulation in the section excavated in "Las Llanadas" deposit, central Cuba. A. Section taken and modified from Figure 1. The excavated segments were enumerated to better understand the graph showing the accumulation. B. Represents the amount of fossil remains accumulated (fragmented and not fragmented) by excavated grid square.

Taphonomic Criteria. The development of taphonomy during the past decades has highlighted multiple factors that have to be taken into consideration for an adequate interpretation about origin of fossil deposits and the preservation of the paleontological materials registered. In this sense, had been used the taphonomic criteria, categories, and concepts developed by FernándezLópez $(1984,1986,1990,1991,1999,2000,2005)$ to define some of the taphonomic events that occurred in the deposit and that were responsible for the origin and differential preservation stages of the extracted materials, and also, the criteria of Domínguez-Rodrigo et al. (2011) and Martínez-López et al. (2012) to identify anthropogenic alteration.

Four types (A-D) presented by Woloszyn and Silva (1977) to describe the presence of terrestrial mammals in Cuban deposits was very useful. In the same way, the five types (E, F, G, H, I) proposed by Acevedo and Arredondo (1982) for the analysis of the deposit's origin and for its classification (Table I).

The characterization of the spatial relationships of the taphonomic entities observed follows the criteria of Holz and Barberena (1994). This methodology groups the entities into different taphonomic classes, depending on the degree of conservation of the anatomical position (degree of bone articulation) and the degree of dispersion of the fossil remains. If we take into account that "Weathering features on fossils can provide evidence of taphonomic processes, and if primary weathering can be distinguished from transport abrasion and diagenetic effects, then primary weathering can give specific information concerning surface exposure of a bone prior to burial and the time period over which bones accumulated" (Behrensmeyer, 1978: 161), then, it was considered necessary to highlight the taphonomic alterations related to weathering factors, based on the six stages of weathering (0-5) proposed by Behrensmeyer (1978) and the weathering criteria of Fernández-López (2000). 
Table I. Typification of the Cuban vertebrates fossil deposits, essentially mammals. (A - D) proposed by Woloszyn and Silva (1977); (E - I) proposed by Acevedo and Arredondo (1982).

\begin{tabular}{|c|c|c|}
\hline Type & Description & Author \\
\hline $\mathbf{A}$ & $\begin{array}{l}\text { Originated by depredation of owls (Tyto). Their nests, generally, are formed at the } \\
\text { entrances to the caves. The remains of its trophic activity accumulate, first, under } \\
\text { the nests, and then, they can be transported by the water and deposited inside the } \\
\text { caves. The composition of these deposits reflects the food preferences of the owl: } \\
\text { relatively small species of mammals, birds, reptiles and amphibians. }\end{array}$ & \multirow[t]{4}{*}{$\begin{array}{l}\text { Woloszyn and Silva } \\
\text { (1977) }\end{array}$} \\
\hline B & $\begin{array}{l}\text { Formed in large cracks, sinks, or casimbas, which act as funnels to capture the } \\
\text { surrounding waters. In this case, the remains of animals that died outside were } \\
\text { deposited in the sink, washed away by the waters. The caves very often represent } \\
\text { totally or partially this type of sink. In cases where it is a matter of filling cracks or } \\
\text { sinks exposed by the exploitation of a quarry, the deposits may be particularly old. }\end{array}$ & \\
\hline $\mathbf{C}$ & $\begin{array}{l}\text { Related to the pre-Columbian anthropic activity, that is to say, aboriginal cave } \\
\text { burials that present remains of animals incorporated to the deposit as a ritual of- } \\
\text { fering, or also to the deposits constituted by residues of the aboriginal's own diet } \\
\text { or zooarchaeological remains. These remains commonly appear in the vicinity of } \\
\text { the entrances to the caves and lack greater antiquity. }\end{array}$ & \\
\hline $\mathbf{D}$ & $\begin{array}{l}\text { Fossiliferous deposits inside the caves, constituted almost exclusively by remains } \\
\text { of bats, and represent the result of the sudden death of the different species that } \\
\text { occupied the cave simultaneously due to the event responsible for it. These depos- } \\
\text { its are older than types A and C. They occur in the innermost areas of the caves. }\end{array}$ & \\
\hline $\mathbf{E}$ & Deposits produced by fluvial floods and originated in the open air. & \multirow{5}{*}{$\begin{array}{l}\text { Acevedo and } \\
\text { Arredondo (1982) }\end{array}$} \\
\hline $\mathbf{F}$ & Originated in the open air and currently contained in fossil soils. & \\
\hline G & $\begin{array}{l}\text { Result of surface accumulations of unburied remains due to falling of live animals } \\
\text { in cavities and losses in caverns. }\end{array}$ & \\
\hline $\mathbf{H}$ & $\begin{array}{l}\text { Accumulations in springs, sources or water deposits where the animals died } \\
\text { drowned or product of the trophic activity of crocodiles. }\end{array}$ & \\
\hline I & Only those remains accumulated in asphalt deposits. & \\
\hline
\end{tabular}

\section{RESULTS AND DISCUSSION}

The features of the deposit that relate to its accumulation history are clearly evident. There is a lack of complete bone remains. Most of the taphonomic entities show abundant fragmentation with evidence of fractures on bone remains. In this sense, the taphonomic elements in general show a high degree of dispersion and an absence of anatomical relationships.

Anthropogenic Alteration. In the case of this site, it is not possible to understand in depth the current conditions of accumulation without assessing the human causes that intervened is its alteration for decades.

The degree of bioturbation by human factors to the fossil assemblage can be separated into three stages: [S1 (prior to 1910)]: the deposit had already been excavated by the time the Cuban naturalist Carlos de la Torre y Huerta visited it for first time. Torre (1910) describes that the deposit had been discovered by the González brothers; that different people took bones from it; and that a captain named Manuel Urrutia kept the best bones to send to Havana but that his death brought an end to all good purpose. Sometime later, a Father Castillo acquired some bones and teeth, which were donated to Dr. Luis Montané Dardé (Anthropological Museum Montané, 
University of Havana, Cuba), and other items, which were donated to Mr. Modesto Lorenzo del Valle (Cuban Lieutenant Colonel of Cavalry of the town of Sancti-Spíritus). No reference is made to whether any of these remains were consulted during subsequent studies. Torre (1910) also mentions a Mr. José Carbó (inhabitant of the region), who also had some bones from the casimba. Probably, all this anthropogenic alteration made before Torres arrived took place on what we term the primary fossil assemblage.

[S2 (1910-1913)]: the section of the deposit where the paleontological material was extracted by us in 2013 had previously been excavated in the early $20^{\text {th }}$ century by Torre (1910) and Brown (1913), from what we term the first version of the remnant fossil assemblage, at which time two new genera and species of sloth were described from the deposit (Matthew 1931, Matthew and Paula, 1959). Torre (1910) describes the type of material extracted during his expedition, which included fossil teeth of Megalocnus and Crocodylus and phalanges of sloth. This expedition is considered, historically, the first scientific intervention of this place by a Cuban naturalist (Carlos de la Torre) in 1910, where the extracted materials were destined for future studies on the Cuban fossil megafauna. The second scientific intervention was in 1911, when Barnun Brown, a remarkable collector from the American Museum of Natural History in New York, accompanied by Carlos de la Torre and his assistant Victor Rodríguez Torralbas, visited the site for a week and extracted numerous bone remains (Brown, 1913; Arredondo, 2011; Goldberg et al., 2017). Brown stated that the bones "...were not plentiful" (Brown, 1913:224) and that nothing new was found over what was reported by Torres in 1910. Brown's extractions in 1913 were made on what we term the second version of the remnant fossil assemblage.

[S3 (After 1913)]: Barbour (1945) mentions numerous fossils bones extracted in 1917 by a Mr. Moreno, a local teacher living in Jatibonico, who, motivated by Barbour himself, contributed more fossil material for the Museum of Comparative Zoology, Harvard University, Cambridge (USA). Moreno's work took place on what we term the third version of the remnant fossil assemblage. In all cases, the methodology used to extract the bones and teeth is unknown. There are no further references to bone extractions after 1917. However, we cannot be certain that there were no interventions between 1917 and our expedition in April 2013, and it is possible that we were facing another version number of the remnant fossil assemblage.

Because we were unable to locate all of the paleontological material extracted previously, is impossible at this point to make a full comparison with the assemblage collected recently, which seems to be significantly smaller than that extracted from Ciego Montero (Cienfuegos, central Cuba), locality where B. Brown, between 1913 and 1918 also made works of collection of paleontological materials of great importance.

Currently, the number of complete and very well preserved fossil material is limited (see Aranda et al., 2017), except for an almost complete radius of Capromys pilorides (Fig. 3a). The assemblage concerned mostly short and round bones and only a few, very fragmented long bones (Fig. 3). Today, we can easily deduce that anthropogenic alteration due to previous "controlled" or uncontrolled fossil bone extraction is a considerable factor in the preservation of the deposit in general.

An abundance of small bones, usually fragmented and/or fractured, would be expected following numerous previous bone extractions, where only a few of them had been registered in publications or scientific communications. All the scientific interventions made before our study have reduced or removed the possibility of making complete or partial reconstructions of individuals from the bones collected by us. 


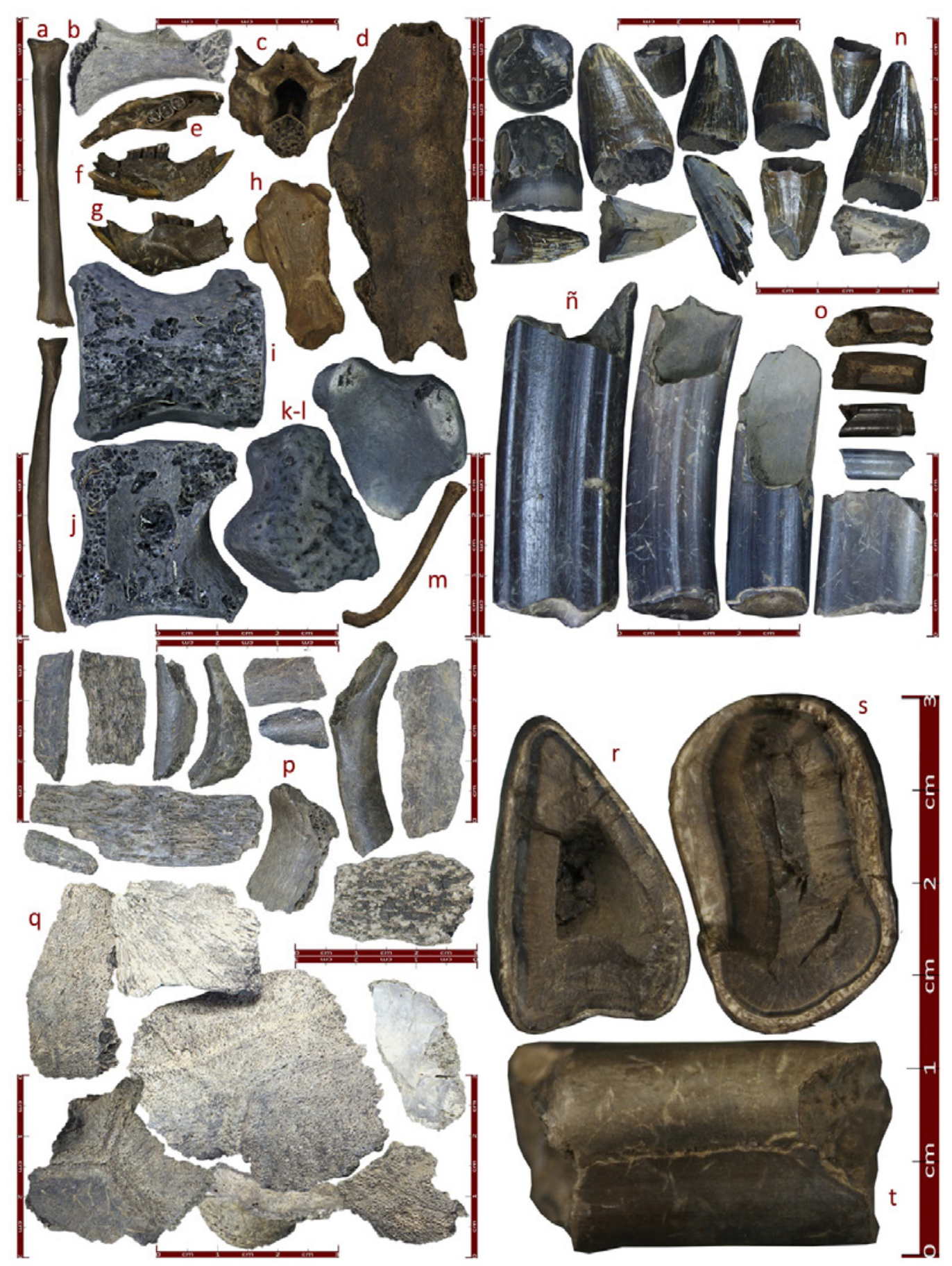

Figure 3. Remnant fossil assemblage from "Las Llanadas" deposit, central Cuba. a, almost complete radius of Capromys pilorides. b, calcaneus of Neocnus gliriformis. c, vertebra of Chilabothrus sp. d, rib fragment. i-j, vertebral body, and k-1, distal end of radius of Megalocnus rodens. e-g, left mandibular rami of Boromys offella in top, lingual and labial views. h, calcaneus and $\mathrm{m}$, clavicle of Capromys pilorides. $\mathrm{n}$, teeth of Crocodylus sp. ñ, molars of Megalocnus rodens. o, four molars of Neocnus gliriformis, in horizontal position. p, rib fragments of megalonichids. q, plastron fragments of testudines. r-t, fragmented teeth of Megalocnus rodens in occlusal and lateral views. 
The Figure 2 shows three well defined points in the excavated area (segments 0-1, 3-4, and 6-7) where most of the bone material has accumulated, like mounds. At those three points there was an almost total absence of complete bones, but there were fragments of teeth, ribs, and short round bones, maybe constituting what remained after the previous selection of specific bones for taxonomic studies. Similarly, Torre (1910) and Brown (1913) also noted that complete and very well preserved bones were not the main quality of the accumulated remains. However, logically, the initial accumulation occurred by natural means.

At this point, the problem is to determine the autochthony or allochthony of fossil materials, independently of human activity as a taphonomic alteration agent. The casimba "Las Llanadas" has some important structural features that favor processes of natural accumulation of bone remains and other materials. The depth of the fissure can be appreciated from both walls of the deposit, the north and south. The fissure could have been served as a natural trap for some species, especially the larger ones, probably because of its weight, which would be a determining factor after a fall.

The presence of water during most of the year can make this a natural watering hole, possibly one of the few in the geography of Jatibonico. Torre (1910) mentions the coincident association of sloth remains with crocodile remains (Crocodylus pristinus $=$ Crocodylus rhombifer), as was also observed in Ciego Montero, which made him think of a different environment from the current one. The same association was recently mentioned by Aranda et al. (2017), who report 39 remains of crocodiles, among which some well-preserved teeth (Fig. 3n), vs. 698 remains of megalonichids.

Origin of the Primary Fossil Assemblage. The genesis of the deposit was strictly natural. From the structural point of view, we agree with Brown (1913) that the water currents were responsible for the current morphology of the karst fissure in which the remains accumulated. In Figure 1A we can see the routes ( 1 and 2 ) that followed the water in the past, which must have dragged many paleontological remains into the fissure. Some of these remains were trapped (the big ones) and others followed course with the water (the small ones), especially, relative to species. Sections 2 and 3 within the crack played an important role in the retention of materials.

These two areas were those of greater contributions of remains during the expeditions mentioned in previous sections. Currently section 3 was excavated in 2013, to which the materials analyzed for this work belong. In addition, due to the muddy nature of sediment the possibility of finding skeletal remains of small vertebrates is almost unlikely.

Type B classification (Table I), corresponds with this deposit, being generated in large cracks, sumps or casimbas that acted as funnels for surrounding waters, dragging materials to their "final" place of deposition. With this type of deposit, the presence of traces of bats is particularly rare, while remains of large mammals, such as sloths and hutias, as well as large birds and large reptiles predominate. Type E classification, of Acevedo and Arredondo (1982), may be used complementarily to classify the deposit because it includes the action of water as the main transportation agent of the remains primarily deposited in open environments.

In addition, according to the characterization of the relationship and the spatial distribution (disarticulation) of the taphonomic elements and entities, the deposit may be considered Class III following the criteria of Holz and Barberena (1994), with subclasses IIIa (complete bones) and IIIb (incomplete or fragmented bones). This last approach it is in correspondence with Paula (1956), Matthew and Paula (1959) criteria. In both cases they did mention about the fragmentary nature of the material collected by Carlos de la Torre between 1910 and 1913 . 
From the point of view of the taphonomic postulate of production, the tapogenic type (Fernández-López, 2000) is almost the only type that is applied. This is because a primary biological entity, produced biogenically, generates several taphonomic conditions, which can be bones and teeth, or fragments of these. Due to the impossibility of establishing an anatomical relationship between the entities generated, and not being able to demonstrate that the biogenic production was directly in the place where the remains were found (autochthony), then it is considered a taphogenic production. This corresponds to the primary characteristics of the deposit and the alteration classes mentioned. Taphogenic production can be identified by establishing a relationship between the density of zoological materials and their degree of fragmentation.

Sloths, for example, make a significant contribution to the total amount of accumulated remains and the total number of species identified. The tooth and bone size of these species is significantly greater than the other vertebrate groups registered in the deposit (except crocodiles). That feature allows generate multiple fragments (taphonomic elements) from one anatomically complete piece (Fig. 3). An exception is some sloth coprolites (Fig. 4a). Taking into account their fragile nature and the impossibility of them being derived from hydraulic currents without sustaining severe damage, it seems possible that these coprolites were generated directly in the deposit.
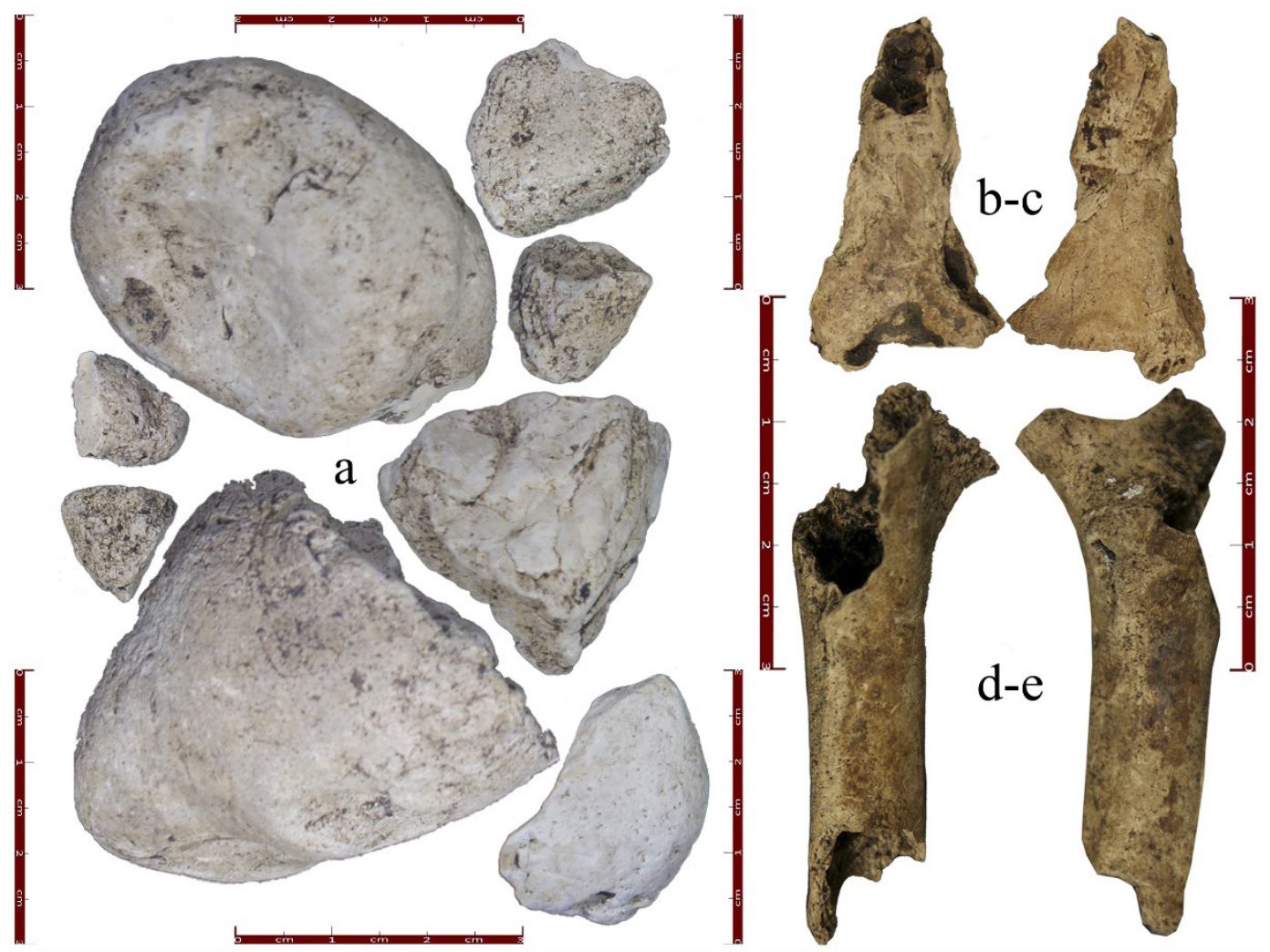

Figure 4. Possible biogenic production. a, coprolites of megalonichids. b-c, medial-distal portion of humerus, and d-e, medialproximal portion of femur of recent Capromys pilorides. 
If we consider the environmental inheritance as a factor that generates allochthony, the determination of autochthony or allochthony is hampered by insufficient data about the residue collected prior to 2013 and by the current absence of coherent stratigraphy. However, almost all of the bones show evidence of dragging by hydraulic action (see below, "Natural Mechanisms of Taphonomic Alteration"). It is a risky to assume full allochthony for the accumulated materials because (1) the accumulation of the remaining product of the transfer does not guarantee its transfer from a paleogeographic area sufficiently far from the accumulation point to be considered all allochthonous and (2) the weathering traces observed in the bone tissue do not suggest high levels of exposure to a biostratinic environment. In this sense, most of the accumulated remains could be considered authoctonus, in condition of "ex situ" or "rolled" (Fernández-López, 2000: 75), that is, displaced to a new stratigraphic position. As noted above ("Accumulation"), they can also be dismissed during previous excavation.

The above factors have contributed to the interpretation of paleobiological information of the past entities to which remains belonged. Until now, in any works published and reviewed the type of associations of fossils is not clarified, if they were found anatomically related, or partially complete. In our excavation, we did not find any evidence pointing to a biogenic production in any case. The remnant fossil assemblage found today can be classified as oryctocoenosis, which is no more than the "... set of fossils that are, or have been found, together" (Fernández-López, 2000: 34).

Mechanisms of Taphonomic Alteration. Factors that influenced the origin of the deposit provide reasons for to explain the oryctocoenosis of neontological (recent material of living species) and paleontological remains. The environments in which the initial processes of accumulation occurred, after the biogenic production of the remains, are inferable. However, the total absence of stratigraphically successive associations makes it impossible to define subsequent paleobiological associations chronologically (Fernández-López, 1986, 2000).

Biostratinomic Stage. As mentioned before, it was impossible to find remains in situ, or any alterations caused by extrinsic factors during the biostratinomic stage, such as carnivorous organisms that leave evidence of their actions through marks on the bones. Torre (1910) infers the possibility of the direct predation of sloths by crocodiles. He mentions as an element in favor of this possibility the fact that the proximal epiphyses of many long bones appear absent and that there are impressions or stripes on the bone surface. However, from the illustrations published in the works of Matthew and Paula (1959), and Goldberg et al. (2017), showing the general appearance of the most important remains collected by Carlos de la Torre, we observe that the bones from Ciego Montero show much better preservation than those from the casimba of the Sierra de Jatibonico (now known as "Las Llanadas").

Of all the remains extracted during our expedition, only a few fragmented pieces of the rodent Capromys pilorides showed that it could suggest the action of predatory organisms, also considering possible human consumption. Regardless of whether these materials are recent (neontological), [Fig. 4 (b-e)] are not excluded from the taphonomic analysis, since they are indicating a bioturbation action, either by natural or anthropic factors. However, these remains do not offer enough information to incorporate them into paleoecological analyzes.

Taphonomic processes of removal are among the most important. Within these, sedimentation is implicit in the analysis, if we consider that before the final accumulation, the paleontological materials were occupying different spaces and were moving to new stratigraphic positions during certain periods. During the time when paleontological materials are being washed away by water, or removed by other types of factors, considerable mechanical alterations have left their marks on the remains [see Fig. 3 (b-1, n-t), Fig. 5 (a-n)]. 


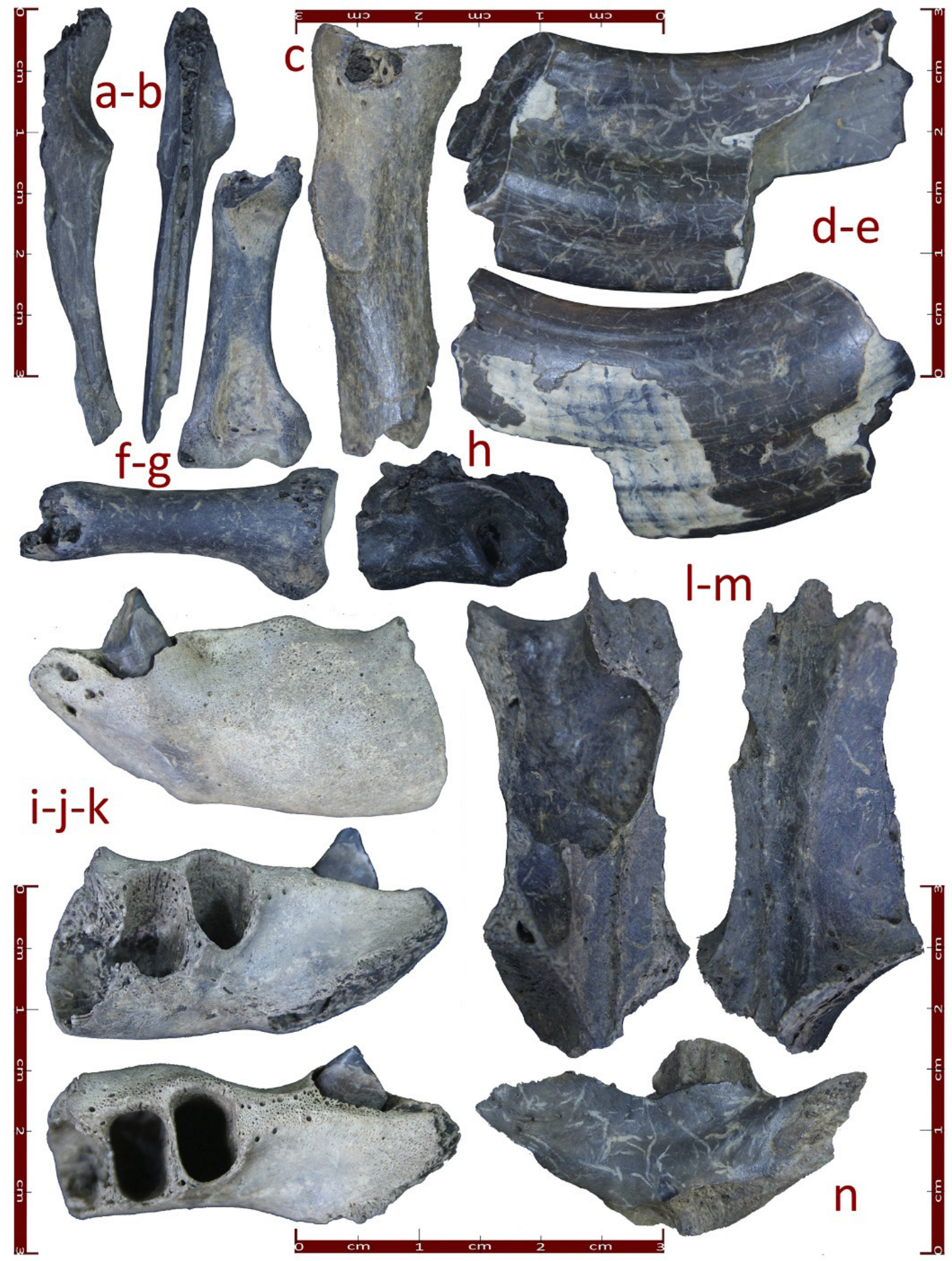

Figure 5. Remnant fossil assemblage from "Las Llanadas" deposit, central Cuba. a-b, ulna of Neocnus gliriformis. c, midproximal fragment of radius of Parocnus browni. d-e, fragmented teeth of Megalocnus roden. f-g, almost complete phalanx of Buteogallus borrasi in ventral-vertical and dorsal-horizontal views, respectively. h, tympanic bone of megalonichids. i-k, left jaw of juvenile Acratocnus antillensis. 1-m, palate fragment of Acratocnus antillensis. n, right jaw of Capromys pilorides. 
At the biostratinomic stage, some signs of abrasion by polishing or in the form of facets with changes in sphericity and roundness of the bones [Fig. 3 (n)] were observed in the accumulated remains. However, because of the presence of crocodile teeth (Crocodylus sp.), we cannot ignore the trophic action exerted by this species, which adds some wear to its teeth.

An analysis of the impact on bone tissue of weathering allows us to infer that disarticulation and dispersion by dragging began long time before, exceeding the third stage proposed by Behrensmeyer (1978). The analysis of natural factors (abiotic and biotic), as well as human factors, played an essential role in determining the macroscopic conservation state of the accumulated remains (Alcántara et al., 2006) and the taphogenic conditions revealed by such processes as fragmentation (natural abiotic and biotic factors) and fracture (natural and anthropogenic factors). Both fragmentation and fracturing are termed taphonomic distortion. This process is clearly seen in almost all of the remains in the deposit (see Figs. 3, 5, and Fig. 6).

Mechanical distortion by hydraulic action or by humidity through time are the most prevalent. Loss of bone tissue can be seen at the edges of some entities, corresponding with drag and mechanical erosion due to transportation factors. As fragmentation is a process that usually occurs after the loss of organic matter, hydrothermal factors (desiccation) and climate (dehydration) have the greatest incidence (Brugal, 1994; Mateos, 2000), also provoking exfoliation and cracking on bone pieces (Hill, 1976; Behrensmeyer, 1978), which may suggest temperature fluctuations during exposure to the palaeoenvironment [see Fig. 3 (n, t), Fig. 5 (d, e)].

Detailed observation of bone tissue shows no deep fissures in most of the remains, suggesting that they were dragged to the point of accumulation before weathering caused fragmentation at the primary deposition site. Therefore, it is possible that, most of the time, the remains were deposited in the substrate in which they were found, or very close to it. The presence of teeth of predators in the reservoir can be linked to its trophic action with respect to the rest of the wildlife, especially megalonquíides and testudinas, which justifies inferring a period with a lacustrine environment.

Other remains show oblique longitudinal grooves in the periosteum that may be related to the mechanical drive by hydraulic action. However, some highly mineralized megalonychid teeth have certain longitudinal fractures [Fig. $3(\mathrm{r}-\mathrm{t})$ ] that can be related to thermal factors during the biostratinomic stage, such as mineralization processes in the fossiliagenetic stage. In addition, fractures in some of the remains [Fig. $3(\mathrm{n}, \mathrm{o})$, Fig. $5(\mathrm{~d}, \mathrm{e})$ ] are adjusted to the fracture patterns (transversal, longitudinal and oblique) described by Alcántara et al. (2006), conditioned by static load by pressure and dynamic load by percussion. In both cases, the criteria of natural action (abiotic and biotic) or human action are present.

Among the natural factors that provoke this kind of fracture pattern are rock or other solid (abiotic) elements, due to geological accidents during the exposure of the remains to a biostratinomic environment. Another kind of natural (biotic) factor could be the pressure generated on the remains (trophic action) by predators, although, as mentioned before, there are no tooth marks (from crocodiles, for example) that suggest this type of action. Finally, anthropogenic alterations produced by paleontological extractions in the early 20th century (Torres, 1910; Brown, 1913) could have caused these fracture patterns. 


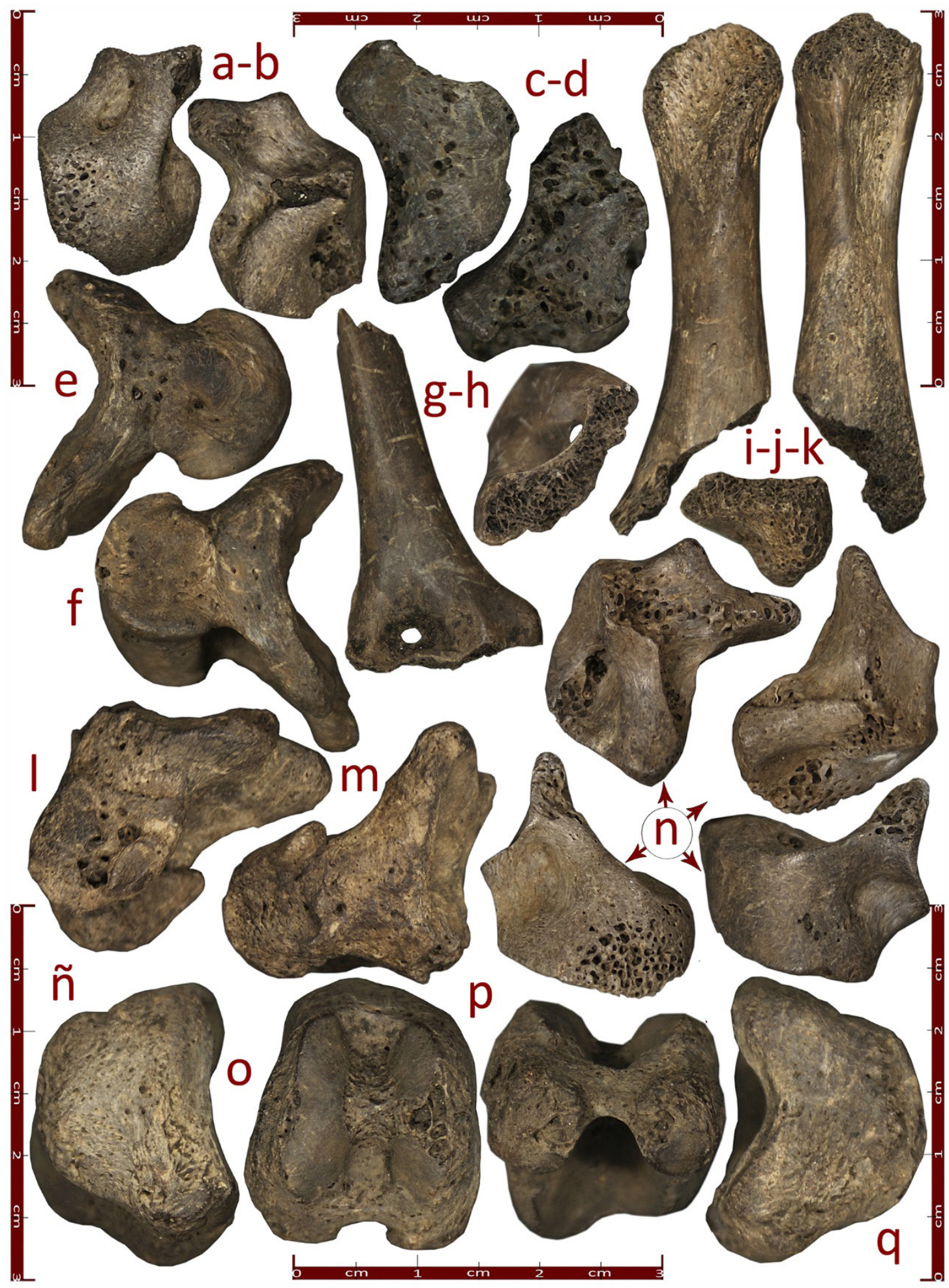

Figure 6. Remnant fossil assemblage from "Las Llanadas" deposit, central Cuba. a-b, ñ, astragalus of Neocnus gliriformis. c-f, l-n, o-q, phalanges of megalocnychids. g-h, distal mid-fragment of humerus of Capromys pilorides in anterior and bottom views, respectively. i-k, humerus of Chelonoidis sp. in dorsal, ventral, and upper views, respectively. 
However, the incidence of the environment or weathering factors in general are not a gradual process over time, since it depends on the levels of exposure of paleontological remains to the biostraninomic environment, and the level of "aggressiveness" of the environment in which the remains were produced. In the case of the remains studied, we can observe that there were no high levels of damage to the bone tissue, which indicates that they were not exposed in situ (where they occurred) during "long" periods of time, or under severe environmental conditions that caused high weathering damages such as those represented by (Behrensmeyer, 1978). Our opinion is that the remains were moved to new locations by hydraulic action. This element is important because it supports the autochthony of paleontological remains under the criterion of "ex situ" or "rolled", according to Fernández-López (2000), mentioned before. The elements in favor of this assumption are the intrinsic factors (age, weight, bone density, etc.) that determine the taphonomic durability of a paleobiological material in the conditions in which it is deposited.

Figure 5 (i-k) shows a mandibular ramus of Acratocnus antillensis, which is the second smallest of the Pleistocene Cuban sloths, after Neocnus gliriformis. This mandibular ramus belongs to a young individual, as is detectable from its relative lack of compact tissue development (high porosity) and its incipient incisor. Note that there is no presence of fissures and cracks resulting from weathering, despite the fact that its juvenile state entails fragility and, therefore, poor durability. Its persistence may be suggest that it was deposited at the site long before the factors of weathering had any bearing on it, or, alternatively, the differential preservation of its bone parts may be suggest that it is a relatively recent individual. The presence of certain other remains, such as an almost complete radius of $N$. gliriformis [Fig. 3 (a)], as well as coprolites [Fig. 4 (a)], are elements to consider that the contribution of paleontological remains to the deposit could have been until recent stages (mid-late Holocene). This is considered by the fragile nature of these remains, especially coprolites.

Other biotic factors (bioerosive agents) also may be responsible for multiple alterations before the final accumulation of the remains, subsequently favoring other processes. An example is the radicular action of plants, as evidenced in some remains, which also causes certain degrees of distortion [Fig. 3 (e-g, i, j), Fig. 5 (d, e, f, g, 1, m, n)]. Alterations similar to marks of bioerosion by insects (dermestids, etc.) are also evident in the bone tissue and could be considered bioerosion signals (Fig. 6). These bone pieces lack parts of their bone tissue, essentially the spongy bone, in the phalanges, astragali, and epiphyses of long bones, among others, and in particular zones, such as those described by Holden et al. (2013). It is not excluded that this absence of tissue may be related to such taphonomic processes as abrasion and distortion, mentioned before, or to chemical dissolution.

Fossildiagenetic Stage. With the available information, we cannot be certain that taphonomic re-elaboration or reworking processes have occurred during the biostratinomic stage. We know that these processes may occur at the point where the bones were dragged and accumulated by hydraulic action. However, the anthropogenic disturbance mentioned before provides a space for disinterment and relocation of accumulated remains, among other conditions, a feature which explains, in part, the positioning of the remains, the absence of coherent stratigraphy, and the evidence of natural deposition processes.

Other mechanisms of taphonomic alteration present in the remains are the sedimentary filling, mineralization and dissolution. The first is associated with the accumulation time of the remains in the sediment, which can be seen inside some skeletal structures, and even in the trabecular tissue exposed in other fragmented structures [Fig. 3 (b, e, i, j, p, r), Fig. 5 (a, b, c), Fig. 6 (a-d)]. This sedimentary fill may have occurred through aspirated flows or through hydraulic gravitational infiltration, constituting a geotropic or geotropic fill, as partial evidence 
that the fossilizing environment in which the remains prevailed was the place where the sediments accumulated. In this sense, the processes of sedimentary filling and mineralization are favored [Fig. 3 (s)]; the permineralization and cementation of the cavities are presented as subprocesses and are essentially the result of abiotic factors, promoting the taphonomic durability of the bone elements despite the variability of alterations present in them.

Finally, the dissolution could be responsible for the loss of bone tissue that resembles small gaps in some areas, mainly in calcaneus bone [Fig. 3 (b, e-g, i, j), Fig. 6], in addition to the weakening of the epiphyses of the long bones, which often show loss of diagnostic features in these areas. This process may have favored the addition, exchange and replacement of organic components by inorganic materials, favoring the preservation of some of the fossilized remains found.

Type of Taphonomic Association and Its Paleoenvironmental Implications. When considering the faunal composition of the paleontological remains found in "Las Llanadas" deposit (Torres, 1910; Brown, 1913; Matthew, 1931; Barbour, 1945; Matthew and Paula, 1959; Goldberg et al., 2017; Aranda et al., 2017) and the density of materials per zoological group, it is possible to infer the existence, at some point, of a lacustrine environment. Associated remains of crocodiles, chelonians, sloths, and hutias, among others (Torres, 1910, Brown, 1913; Aranda et al., 2017) point to very well defined interspecific dynamics. The sea level would have to have been significantly higher than it is today for these conditions to prevail.

If we analyze sea levels during the interval corresponding to the Upper Pleistocene (Fig. 7), we see that the paleogeographic panorama of the Cuban archipelago showed stages where the terrestrial spaces were very reduced with respect to previous stages, a reduction that should have favored considerably the extinction processes of the, fundamentally, terrestrial fauna. And we also see that during the warming maxima of the Sangamon Interglacial (130-120 kyr BP) the mean sea level was above the current global level (Iturralde-Vinent, 2003).

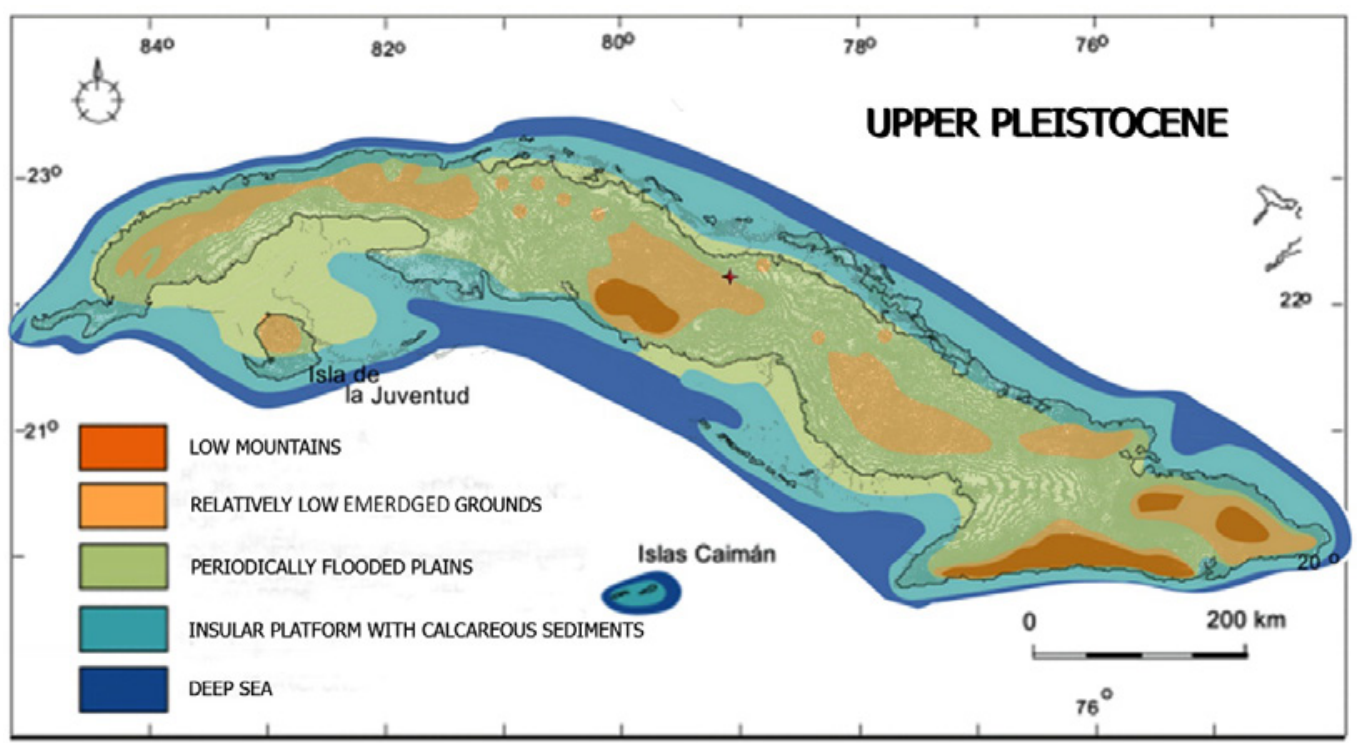

Figure 7. Stages of maximum flood during the Upper Pleistocene. The fossil deposit "Las Llanadas" occupies a slightly flooded space, which justifies the lacustrine fossil fauna found. Map taken and modified by Iturralde-Vinent (2003). 
The chemical-physical hydrodynamics of ground and surface water in the karst territories of terrestrial and marine ecosystems were conditioned by the increase and decrease in sea level. From $120 \mathrm{kyr}$ BP to 25-20 kyr BP, gradual decreases in sea level are recorded (Lambeck and Chappell, 2001), with irregularly spaced increases all remaining below the above-mentioned peak, which again evidences an upwelling of the submerged platforms and an increase in the mechanical and chemical denudation processes on the karst, related to the runoff and infiltration of surface waters. These processes could have favored the structural formation of the deposit, and dragged to the same fissure the large amount of fossil material of fauna that inhabited the region.

It is known that sea level variations have continued to play an essential role in the modification of the coastline and in the amount of land that has emerged, as well as in the type of vegetation and ecological conditions for the development of past biota in the Caribbean area in general and in the Cuban territory (Pregill and Olson, 1981; Ortega and Arcia, 1982; Iturralde-Vinent, 2003, 2005; Pajón et al., 2006; Peros et al., 2007, among others). Specifically, it is known that an elevation of sea level between +1 and $+7 \mathrm{~m}$ has been recorded by Mylroie and Carew (1988) for a period of time between $85-70 \mathrm{kyr} \mathrm{BP}$, while sea level positions similar to the current ones were recorded for the period between 49-37 kyr BP.

As well illustrated in Figure 7, the location of the fossil deposit occupies an area that remained slightly submerged for a time not yet estimated, but inferred in thousands of years. We cannot cite investigations that specify exactly when the specific area in which the deposit was partially or completely emerged. However, the relative proximity to the emerged lands (according to the paleogeography proposed by Iturralde-Vinent, 2003), between 140-125 ky BP, suggests that in the next thousands of years the area where Las Llanadas is located had conditions for development of a lacustrine environment that justifies its taxonomic inventory (see Aranda et al., 2017). The paleoecological information provided by these authors seems to indicate at least four stages (Iturralde-Vinent, 2003; Condis, 2010) or intervals (Silva et al., 2007) where climatic changes followed by variations in sea level affected the paleoecology of the Cuban archipelago between the last 20-3 kyr BP to the present.

Even if evidence of lacustrine environments has been recorded in the aforementioned period, it does not mean that they can be an agent of contribution of remains to the deposit under study. They are excluded due to the altitudinal arrangement of the paleontological site, which is between 185-195 m a. s. 1., whereas nearby areas rise to 225-260 m a. s. 1. (Martínez-López et al., 2015).

\section{CONCLUSIONS}

The geographic area of the fossil deposit "Las Llanadas", in its current morphology, reflects some essential features for the interpretation of the origin and formation of the karst structures present in it. The fossil deposit under consideration is a dissolution karst fissure (Martínez-López, 2013), generated by chemical and mechanical denudation processes because of changes in sea level between $140 \mathrm{kyr}$ BP (Iturralde-Vinent, 2003), and almost the last stage of the Holocene (8-4 kyr BP).

The evidence of these processes can explain how the paleontological remains were accumulated in the deposit. The taphonomic study of the accumulated fossil material provides clear evidence that trawling by surface water currents is the main agent of accumulation of this deposit, which corresponds to the opinions of other authors (Woloszyn and Silva, 1977; Acevedo and Arredondo, 1982; Arredondo, 1999; Silva et al., 2007; Condis et al., 2008; Condis, 2010) about the formation of fossil accumulations in the Cuban deposits. 
It is important to note that the remains found have no evident bite marks of predators, except for the recent remains, which may be related to the current human consumption of the fauna. If there had been trophic interactions between species, such as sloths and crocodiles, we would have expected to see bite marks mainly on parts such as humerus, radii, femurs, tibia, fibulas and skulls. Although some proximal and distal radii were found, none showed any evidence of this type of interaction. Naturally, the fact that trophic interactions are not evident in bone remains does not mean that lake environments, with their relevant intra- and interspecific interactions, have not been successful in the environment in which the deposit was created.

It should be remembered that the human action referred to in the course of this work has considerably modified the "stratigraphy" or primary disposition of fossil accumulation, as well as the spatial distribution of the remains and the essential anatomical relationships between them, that could have provided a lot of information for taphonomic, taxonomic and paleoenvironmental interpretations. The high degree of dispersion and the absence of anatomical relationships make it impossible to establish which elements may have been directly produced (biogenic production) within the site and, therefore, makes paleoecological analysis difficult on the basis of taphonomic alterations. There is no doubt that the human alteration of deposits in the twentieth century limits making inferences about this type of production, and the identification of certain trophic relationships among the recorded species.

However, the incorporation of historical elements related to the stages of anthropogenic alteration is an element to consider for future works of taphonomic interpretation in cuban paleontological deposits (if applies), especially of vertebrates. It is very likely that a large part of our fossil deposits have suffered one or several previous interventions, which forces us to take into account these elements for an adequate interpretation of current fossil associations and to define them as primary or remnants, and then, to delimit the real scope of our taphonomic interpretation, along with the new methods and knowledge that allow us to extract more information.

\section{ACKNOWLEDGEMENTS}

Our thanks to all those who made the field work possible in "Las Llanadas", but especially to Gilberto Silva Taboada, Matthew Charles Peros, Lázaro Wiliam Viñola-López, and Roberto Rodríguez Suárez, who reviewed an earlier version of the manuscript; to the Institute of Tropical Geography, colleagues Dr. Gustavo Martín Morales and MSc. Jorge Olivera Acosta, for his contribution to geographic information; to MSc. Ernesto Aranda Pedroso, for his valuable contribution during the field and laboratory work; to Lic. Jesús M. Pajón Morejón and Dr. Reinaldo Rojas Consuegra for their contribution to the measurements of deposits during the field work; to our colleague and friend MSc. José Eusebio Chirino Camacho, José Ángel Rodríguez Sánchez (Titi), to MSc. Armando Falcon Méndez, and Carlos Alemán Luna, Alexander Valdivia Lara and Alexis Pérez Trujillo (Fran), for the help during the field work; Osvaldo Jiménez Vázquez and Lázaro Wiliam Viñola-López for their important contribution in the identification of fossil materials; Dr. Efren Jaimez Salgado, Institute of Geophysics and Astronomy, Cuba, for his valuable views on the characterization of soils and sediments; to Suzanne Needs, for all her important suggestions and corrections in this work. 


\section{LITERATURE CITED}

Acevedo-González, M. 1983. Observaciones sobre hipótesis recientemente anunciadas acerca del Plioceno y Pleistoceno de Cuba occidental. Ciencias de la Tierra y del Espacio, 7: $37-56$.

Acevedo-González, M., and O. Arredondo. 1982. Paleozoogeografía y geología del cuaternario de Cuba: características y distribución geográfica de los depósitos con restos de vertebrados. IX Jornada Cient. Int. Geol. Paleontol. ACC., pp. 59-70.

Alcántara, V., R. Barba, J. M. Barral, A. B. Crespo, A. I. Eiriz, A. Falquina, S. Herrero, A. Ibarra, M. Megías, M. Pérez, V. Pérez, J. Rolland, J. Yravedra, A. Vidal, and M. DomínguezRodrigo. 2006. Determinación de procesos de fractura sobre huesos frescos: un sistema de análisis de los ángulos de los planos de fracturación como discriminador de agentes bióticos. Trabajos de Prehistoria, 63 (1): 37-45. ISSN 0082-5638.

Aranda, E., J. G. Martínez-López, O. Jiménez, C. Alemán, and L. W. Viñola. 2017. Nuevos registros fósiles de vertebrados terrestres para Las Llanadas, Sancti Spíritus, Cuba. Novitates Caribaea, 11: 115-123.

Arceo, S., and E. Salinas. 1994. Evaluación del potencial natural de los paisajes para la actividad agropecuaria del municipio de Yaguajay, (provincia Sancti-Spíritus, Cuba). Geographicalia, 31: 3-16.

Arredondo, C. 1999. Los edentados extintos del Cuaternario de Cuba. Tesis en opción al grado científico de Doctor en Ciencias Biológicas. Facultad de Ciencias Naturales. Instituto Superior Pedagógico “E. J. Varona”, La Habana, 144 pp. (Inedit).

Arredondo, C. 2011. Los perezosos extintos. In Mamíferos en Cuba (R. Borroto and C. A. Mancina Eds.). UPC Print Vaasa, Finlandia, pp. 28-37.

Arredondo, C., and R. Villavicencio-Finalet. 2004. Tafonomía del Depósito Arqueológico Solapa del Megalocnus en el Noroeste de Villa Clara, Cuba. Revista Biología, La Habana, Cuba, 2 (18): 160-171.

Barbour, T. 1945. Mammals of long ago. In A naturalist in Cuba (Chapter X). Little, Brown, Boston, pp. 232-243.

Behrensmeyer, A. K. 1978. Taphonomic and ecologic information from bone weathering. Paleobiology, 4: 150-162.

Brown, B. 1913. Some Cuban fossils: a hot spring yields up the bones animals that lived before the Advent of Man. The Journal of the American Museum, 13: 221-228.

Brugal, J. P. 1994. Introduction générale action de l'eau sur les ossements et les assemblage's fossils. Artefacts 9 (Outillage pen elabore en os et en bois de cervides), IV: 121-129.

Comisión Nacional De Nombres Geográficos, 2000. Diccionario Geográfico de Cuba. Oficina Nacional de Hidrografía y Geodesia; La Habana, Cuba. 386 pp. ISBN: 959-7049-08-2. 
Condis, M. M. 2010. Inferencias paleoecológicas sobre especies de la mastofauna cuaternaria cubana, conservadas en el depósito superficial de La Caverna Geda, Pinar del Río, Cuba. Tesis en Opción al Grado de Doctoren Ciencias, Programa Cooperado: "Desarrollo Sostenible Bosques Tropicales. Manejo Forestal y Turístico", Universidad de Pinar del Río, Cuba y Universidad de Alicante, España (Tutora: Dra. María Teresa Alberdi). 196 pp. (Inedit).

Condis, M. M., O. Jiménez Vázquez, and F. Balseiro. 2008. Mamíferos del Registro Fósil y Asociados a Sitios Arqueológicos y Paleontológicos Contentivos de Mamíferos de Cuba (Terciario y Cuaternario). In http://www.cubaarqueologica.org/index.php?q=node/228, Submitted in 2011.

Díaz-Franco, S. 2005. Los mamíferos fósiles del yacimiento “Las Breas de San Felipe”, Martí, Matanzas, Cuba. Tesis de Maestría. Facultad de Biología, Universidad de La Habana, Cuba, 56 pp. (Inedit).

Domínguez-Rodrigo, M., S. R. Ferrnández-López, and L. Alcalá. 2011. How Can Taphonomy be defined in the XXI Century. Journal of Taphonomy, 9 (1): 1-13.

FAO (Organización de las Naciones Unidas para la Agricultura y la Alimentación). 2009. Guía para la descripción de suelos. Traducido y adaptado al castellano por Ronald Vargas Rojas (Proyecto FAO - SWALIN. Nairobi, Kenya-Universidad Mayor de San Simón, Bolivia). Cuarta Edición. Roma, 110 pp.

Fernández-López, S. R. 1984. Nuevas perspectivas de la tafonomía evolutiva: tafosistemas y asociaciones conservadas. Estudios Geol., 40: 215-224.

Fernández-López, S. R. 1986. La Tafonomía: un subsistema conceptual de la Paleontología. COL-PA (publicaciones del departamento de paleontología), 41: 9-34.

Fernández-López, S. 1990. El significado de la Autoctonía/Aloctonía tafonómica. Reunión de Tafonomía y Fosilización, pp. 115-124.

Fernández-López, S. 1991. Taphonomic concepts for a theoretical Biochronology. Revista Española de Paleontología, 6: 37-49.

Fernández-López, S. 1999. Tafonomía y fosilización. In Tratado de Paleontología. (B. Meléndez, ed.), Consejo Superior de Investigaciones Científicas. Madrid, pp. 51-107.

Fernández-López, S. R. 2000. Temas de Tafonomía. Departamento de Paleontología, Facultad de Ciencias Geológicas, Madrid, 167 pp.

Fernández-López, S. R. 2005. Alteración tafonómica y tafonomía evolutiva. Bol. R. Soc. Esp. Hist. Nat. (Sec., Geol.), 100 (1-4): 149-175. ISSN 0583-7510.

Goldberg, S., M. J. Novacek, and G. Alayón. 2017. The history of scientific relations between Cuba andthe American Museum of Natural History (AMNH): 160 Years of Collecting and Collaborating (1857-2017). La historia de las relaciones científicas entre Cuba y el American Museum of Natural History (AMNH): 160 Años de Colección y Colaboración (1857-2017). Printed in the United States of America. ISBN 978-0-9852016-6-1, 133 pp. 
Hill, A. P. 1976. On carnivore and weathering damage to bone. Current Anthropology, 17 (2): 335-336.

Holden, A. R., J. M. Harris, and R. M. Timm. 2013. Paleoecological and Taphonomic Implications of Insect-Damaged Pleistocene Vertebrate Remains from Rancho La Brea, Southern California. PLOS ONE (www.plosone.org), 8 (7): 1-9.

Holz, M., and M. C. Barberena. 1994. Taphonomy of the South Brazilian Triassic Paleoherpetofauna: patter of death, transport and burial. Paleogeography, Paleoclimatology, Paleoecology, 107: 179-197.

Instituto de Suelos de Cuba, Ministerio de la Agricultura. 1999. Nueva versión de clasificación genética de los suelos de Cuba. Editorial AGRINFOR, La Habana, Cuba. 53pp. ISBN: 959246-022-I.

Iturralde-Vinent, M. A. 1972. Estudio cuantitativo de la actividad del Carso en Cuba. Voluntad Hidráulica, 10 (23): 41-47.

Iturralde-Vinent, M. A. 2003. Ensayo sobre la paleogeografía del Cuaternario de Cuba. V Congreso De Geología y Minería, Ecología Del Cuaternario, Geomorfología y Karst. Memorias GEOMIN 2003, La Habana, 24-28 de marzo, pp. 54-74. ISBN 959-7117-11-8.

Iturralde-Vinent, M. A. 2005. La Paleogeografía del Caribe y sus implicaciones para la biogeografía histórica. Revista del Jardín Botánico Nacional, 25-26: 49-78. 2004-2005.

Iturralde-Vinent, M. A., and R. D. E. Macphee. 1999. Paleogeography of the Caribbean Region: implications for Cenozoic biogeography. Bulletin of the American Museum of Natural History, 238: 1-95.

Iturralde-Vinent, M. A., and R. D. E. Macphee. 2004. Los mamíferos terrestres de las Antillas Mayores: Notas sobre su paleogeografía, biogeografía, irradiaciones y extinciones. Actas de la Academia de Ciencias de la República Dominicana, 19 pp.

Iturralde-Vinent, M. A., R. D. E. Macphee, S. Díaz-Franco, R. Rojas-Consuegra, W. Suárez, and A. Lomba. 2000. Las Breas de San Felipe, a Quaternary Fossiliferous Asphalt Seep near Martí (Matanzas Province, Cuba). Caribbean Journal of Science, 36 (3-4): 300-313.

Jaimez, E., and D. A. Gutiérrez. 2010. Nueva clasificación genética de las cuevas de Cuba. Centro Nacional de Derecho de Autor (CENDA), No. 01334-1334, 39 pp. (Inedit).

Jiménez, O., M. M. Condis and E. García. 2005. Vertebrados post-glaciales en un residuario fósil de Tyto alba scopoli (Aves: Tytonidae) en el occidente de Cuba. Revista Mexicana de Mastozoología, 9: 85-112.

Lambeck, K., and J. Chappell. 2001. Sea Level Change Through the Last Glacial Cycle. Science, 292: 679-686.

Martínez-López, J. G. 2013. Caracterización geográfca del área paleontológica "Las Llanadas" (Sancti Spíritus, Cuba), mediante el uso de las tecnologías de la Geomática. Tesina, Instituto de Geografía Tropical, La Habana, Cuba, 57 pp. (Inedit). 
Martínez-López, J. G., C. Arredondo, R. Rodríguez, and S. Díaz-Franco. 2012. La tafonomía en la interpretación de depósitos humanos en contextos arqueológicos. CATAURO. Revista Cubana de Antropología. Fundación Fernando Ortiz, 12 (23): 39-53. ISSN 1681-7842.

Martínez-López, J. G., J. M. Pajón, J. Issac, A. Falcón, and G. Martín. 2015. Capítulo 2: Geología y Geografía. [Yacimiento Paleontológico "Las Llanadas", Municipio Yaguajay, Provincia de Sancti Spíritus, Cuba Central (G. Silva and E. Chirino Eds.)]. Informe Científico Técnico del MNHNC, pp. 3-19. (Inedit).

Mateos, A. 2000. Fracturation anthropique intentionnelle sur mandibules et phalanges dans le niveau VIII de la Grotte de las Caldas (Asturies Spagne). Prehistoire europeenne, 16-17: $255-270$.

Matthew, W. D. 1918. Skeletons of the ground sloth in the Havana and American museums. American Museum Journal, 18 (4): 312-313.

Matthew, W. D. 1919. Recent discoveries of fossil vertebrates in the West Indies and their bearing on the origin of the Antillean fauna. Proceedings of the American Philosophical Society, 58 (3): 161-181.

Matthew, W. D. 1931. Genera and new species of ground sloths from the Pleistocene of Cuba. American Museum Novitates, 511: 1-5.

Matthew, W. D., and C. de Paula Couto. 1959. The Cuban edentates. Bulletin of the American Museum of Natural History, 117: 1-56, lams. 1-42.

Mayo, N. 1970. Depósitos pleistocénicos de los cauces subterráneos abandonados de la Sierra de los Órganos: evidencias de periodos pluviales. Academia de Ciencias de Cuba, Actas, 2: $57-62$.

Morgan, G. S., R. Franz, and R. I. Crombie. 1993. The Cuban Crocodile, Crocodylus rhombifer, from Late Quaternary Fossil Deposits on Grand Cayman. Caribbean Journal of Science, 29 (3-4): 153-164.

Mylroie, J. E., and Carew, J. L. 1988. Solution Conduits as Indicators of Late Quaternary Sea Level Position. Quaternary Science Reviews, 7: 55-64.

Núñez [Jiménez], A., N. Viña, M. Acevedo, J. Mateo, M. A. Iturralde, and A. Graña. 1988. Cuevas y Carso. Editorial Científico-Técnica. Ciudad de La Habana, Cuba. 431 pp.

Ortega [Sastriques], F., and M. I. Arcia. 1982. Determinación de las lluvias en Cuba durante la glaciación del Wisconsin mediante los relictos edáficos. Ciencias de la Tierra y el Espacio, 4: 85-104.

Pajón, J. M., I. Hernández, and Y. Estevez. 2006. Paleoregistros de las variaciones del nivel del mar en el Caribe durante el pleistoceno-holoceno. Conexión con problemas de la arqueología cubana. Memorias de la VIII Conferencia Internacional Antropologia "La Antropologia ante los nuevos retos de la humanidad". Ciudad de La Habana, Cuba, noviembre 27-30 del 2006, 13 pp. 
Paula Couto. C. de. 1956. On two mounted skeletons of Megalocnus rodens. Journal of Mammalogy, 37 (3): 423-427.

Peros, M. C., E. Reinhardt, H. P. Schwarcz, and A. M. Davis. 2007. High-resolution paleosalinity reconstruction from Laguna de la Leche, north coastal Cuba, using Sr., O, and C isotopes. Science Direct (Palaeogeography, Paleoclimaology, Palaeoecology), 245: 535-550.

Pregill, G. K., and S. L. Olson. 1981. Zoogeography of the West Indian Vertebrates in relation to pleistocene climatic cycles. Annual Review of Ecology and Systematics, 12: 75-98.

Rojas-Consuegra, R., O. Jiménez, M. M. Condis-Fernández, and S. Díaz-Franco. 2012. Tafonomia y paleoecologia de un yacimiento paleontológico del cuaternario en la Cueva del Indio, La Habana, Cuba. Espelunca Digital, 12: 15. ISSN 2072-5892.

Skwaletski, E., and M. A. Iturralde-Vinent. 1971. El Carso y la construcción hidrotécnica en Cuba. Voluntad Hidráulica, 9 (20): 41-47.

Silva, G. 1974. Fossil Quiroptera from Cave Deposits in Central Cuba, with description of two new species (Genera Pteronotus and Mormoops) and the first West Indian record of Mormoops megalophylla. Acta Zoologica Cracoviensia, 19 (3): 33-74.

Silva, G., W. Suárez, and S. Díaz-Franco. 2007. Compendio de los mamíferos terrestres autóctonos de Cuba: vivientes y extinguidos. Ediciones Boloña, 465 pp. ISBN 978-9597126-64-5.

Torre [y Huerta], C. de la. 1910. Excursión a la Sierra de Jatibonico: osamentas fósiles de Megalocnus rodens o Myomorphus cubensis: comprobación de la naturaleza continental de Cuba a principios de la época Cuaternaria. Anales de la Academia de Ciencias Médicas, Físicas y Naturales de la Habana, 47: 204-217.

Torre [y Huerta], C. de la. 1917. Nuevas especies de mamíferos fósiles de Cuba y otras Antillas. Mem. Soc. Cubana Hist. Nat. "Felipe Poey”, 2 (6): 234-251.

Torre [y Huerta], C. de la, and W. D. Matthew. 1915. Megalocnus and other Cuban ground sloths (Abstract). Bulletin of the Geological Society of America, 26: 152.

White, J. L., and R. D. E. MacPhee. 2001. The sloths of the West Indies: a systematic and phylogenetic review. In Biogeography of the West Indies: Patterns and perspectives (C. A. Woods and F. E. SergiIe, Eds.), 2nd edn., CRC Press, pp. 201-235.

Woloszyn, B. W., and G. Silva. 1977. Nueva especie fósil de Artibeus (Mammalia: Chiroptera) de Cuba, y tipificación preliminar de los depósitos fosilíferos cubanos contentivos de mamíferos terrestres, Poeyana, 161: 1-17.

[Recibido: 21 de agosto, 2018. Aceptado para publicación: 28 de noviembre, 2018] 